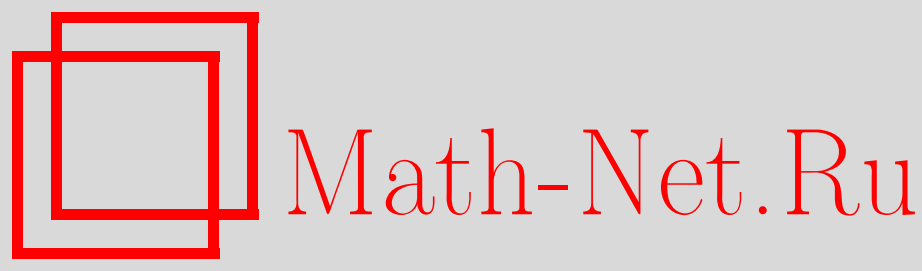

М. Беккариа, Б. Г. Конопельченко, Д. Ландольфи, Л. Мартина, А. К. Погребков, Солитоны в размерностях $1+1$ и $2+1, T M \Phi, 2012$, том 172, номер 2, 179-180

DOI: https://doi.org/10.4213/tmf8401

Использование Общероссийского математического портала Math-Net.Ru подразумевает, что вы прочитали и согласны с пользовательским соглашением http://www . mathnet.ru/rus/agreement

Параметры загрузки:

IP: 54.197 .130 .99

26 апреля 2023 г., 18:13:22

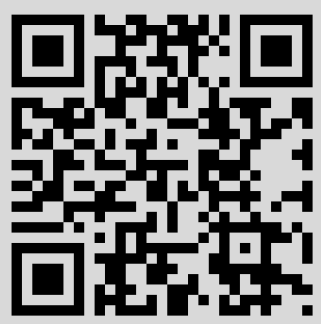




\section{СОЛИТОНЫ В РАЗМЕРНОСТЯХ $1+1$ И $2+1$}

Этот выпуск журнала "Теоретическая и математическая физика" основан на докладах, представленных на конференции "Solitons in $1+1$ и $2+1$. DS, KP and all that", которая проводилась в г. Лечче, в Университете Саленто (ранее Университет Лечче) 13-14 сентября 2011 г. Конференция была посвящена 70-летию выдающихся ученых, профессоров Университета Саленто Марко Бойти и Флоры Пемпинелли. Принимая во внимание круг научных интересов М. Бойти и Ф. Пемпинелли, участники конференции в основном концентрировались на теории нелинейных интегрируемых уравнений и ее приложений, тем самым подчеркивался выдающийся вклад этих ученых в данную область исследований. Результаты М. Бойти и Ф. Пемпинелли хорошо известны специалистам по методу обратной задачи рассеяния. Прежде всего следует отметить здесь их работу (в соавторстве с Л. Мартином и Дж. Леоном) об экспоненциально локализованных солитонных решениях уравнения Дэви-Стюартсона I. Эта работа дала первый пример таких решений для $(2+1)$-мерных уравнений. В последнее время М. Бойти и Ф. Пемпинелли создали и активно развивают специальный подход в рамках метода обратной задачи рассеяния, названный "методом расширенной резольвенты". Этот подход позволил существенно расширить область применимости самого метода обратной задачи рассеяния к исследованию прямых и обратных задач рассеяния в случаях, когда потенциалы оператора Лакса обладают нетривиальным асимптотическим поведением. С помощью этого подхода были исследованы решения уравнения Кадомцева-Петвиашвили I, которые можно рассматривать как возмущения многосолитонных решений. В представленной в этом выпуске статье М. Бойти и Ф. Пемпинелли (в соавторстве с А. К. Погребковым) приведены некоторые новые результаты, посвященные расширению метода обратной задачи рассеяния на класс решений уравнения Кадомцева-Петвиашвили II, являющихся возмущением чисто солитонных решений посредством быстро убывающих функций.

Марко Бойти и Флора Пемпинелли приехали в Лечче, когда Факультет физики был только что создан, в 1968 г. Они были в числе организаторов группы нелинейной физики в Университете Лечче и ее активными членами. Необходимо подчеркнуть их огромный организационный вклад в область нелинейных исследований и развитие международной научной кооперации. В 1979 г. они организовали в Лечче первую конференцию, названную "Nonlinear Evolution Equations and Dynamical Systems" (сокращенно NEEDS). В дальнейшем три другие конференции NEEDS были организованы в Галлиполи в 1985, 1991 и 1993 гг., шесть конференций "Nonlinear Physics: Theory and Experiment" были организованы в 1995, 2002, 2004, 2006, 2008 и 2010 гг. и конференция "Nonlinearity, Integrability, and All That: Twenty Years After NEEDS'79" была проведена в 1999 г. (тоже в Галлиполи). Эти конференции собирали вместе квалифицированных ученых и молодых исследователей, изучавших нелинейные науки, и предоставляли замечательные возможности для обсуждений новых результатов и достижений, равно как и перспектив для участников из 20 стран: Италии, России, Великобритании, Франции, США, Южной Африки, Болгарии, Украины, Польши, Румынии, Испании, Израиля, Индии, Австралии, Греции, Канады, Финляндии, Голландии, Гонконга, Германии и Швейцарии. 
Марко Бойти и Флора Пемпинелли были в числе организаторов Консорциума E.I.N.S.T.E.IN (European Institute for Nonlinear Studies via Transnationally Extended INterchanges), играющего существенную роль в организации сотрудничества между учеными Европы и бывшего Советского Союза. Основная идея создания этого Консорциума состояла в создании научной среды, которая позволит ученым свободно и регулярно взаимодействовать. На базе этого Консорциума координировались два гранта ИНТАС $(1993,1999$ гг.) и были проведены два совместных конкурса с Российским фондом фундаментальных исследований (2006, 2008 гг.). М. Бойти является президентом Консорциума E.I.N.S.T.E.IN.

Этот выпуск журнала "Теоретическая и математическая физика" включает бо́льшую часть докладов, сделанных на конференции "Solitons in $1+1$ и $2+1$. DS, KP and all that". Все они прошли стандартные процедуры рецензирования и редактирования. С нашей точки зрения, учитывая качество представленных работ, данные публикации создают хорошее представление о современном состоянии дел в данной области и обращают внимание на результаты, что и должно стимулировать заинтересованного читателя.

Конференция была организована М. Беккариа, Б. Г. Конопельченко, Дж. Ландольфи и Л. Мартиной при финансовой поддержке Университета Саленто, Министерством среднего и высшего образования и науки Италии (PRIN 2008) и Консорциумом E.I.N.S.T.E.IN. Организаторы благодарят Российский фонд фундаментальных исследований за поддержку российских участников.

Организаторы также благодарны Университету Саленто и Факультету физики за техническую поддержку конференции. В частности, они благодарят М. К. Джерарди, Д. Дельанна, Ф. Спанья и П. Санто за помощь во время конференции. Редакторы этого специального выпуска благодарят всех авторов, приславших свои статьи.

Наконец, организаторы благодарны Редакционной коллегии журнала "Теоретическая и математическая физика" за публикацию этих трудов.

Лечче, сентябрь 2011 г.

М. Беккариа, Б. Г. Конопельченко, Дж. Ландольфи, Л. Мартина, А. К. Погребков 